\title{
Preceramic, Aceramic or Early Ceramic? The radiocarbon dated beginning of the Neolithic in the Aegean
}

\author{
Agathe Reingruber \\ Berlin, DE \\ a.reingruber@ozonline.de
}

\begin{abstract}
The Pre-Pottery-Neolithic refers to a period in the Eastern Mediterranean when ceramic containers were not yet in use (although small objects made of clay were already being created). This concept, which reflects a specific and quite unique stage in the development of human history, was introduced to Aegean prehistory under the term of Preceramic during the 1950's (e.g., in ArgissaMagoula and Sesklo). Shortly thereafter, a different term, the Aceramic, was applied in the Aegean (e.g., in Knossos) for levels devoid of pottery, although ceramic products were supposedly used in the wider region. In some cases, the thin levels interpreted as Preceramic or as Aceramic contained sherds that were regarded as being intrusive from above (e.g., Argissa-Magoula, Franchthi Cave). The new sequences of radiocarbon dates allow a more precise description of this early period and thereby contribute, not least, also to the clarification of terminological issues.
\end{abstract}

IZVLEČEK - Predkeramični neolitik označuje obdobje, ko v vzhodnem Sredozemlju keramične posode še niso bile v uporabi (čeprav so majhne predmete iz žgane gline že izdelovali). Koncept, ki se nanaša na določeno in precej posebno stopnjo v našem zgodovinskem razvoju, je bil z imenom "predkeramični' vpeljan v egejsko prazgodovino v petdesetih letih prejšnjega stoletja (npr. v Argissa-Magouli in Sesklu). Kmalu za tem ga je nadomestil 'akeramični' neolitik (npr. v Knossosu), ki je označeval plasti brez keramičnih posod, čeprav so bile v širši regiji domnevno že poznane. V nekaterih primerih so tanke naselbinske plasti interpretirali kot 'predkeramične' ali 'keramične' s fragmenti lončenine, ki naj bi vanje prišli iz zgornjih plasti (npr. Argissa-Magoula, jama Franchthi). Nove sekvence radiokarbonskih datumov omogočajo še posebno natančne predstavitve teh zgodnjih obdobij, in nenazadnje tudi boljše terminološke pojasnitve.

KEY WORDS - Preceramic; Aceramic; Initial Neolithic; Meso-Neolithic interface; radiocarbon dates; Aegean

The terminology: the impacts of Near Eastern and Anatolian research

Modern archaeology saw its beginnings around 1950 with the introduction of natural sciences into archaeological methodology. In 1947, when Robert and Linda Braidwood from the University of Chicago started their interdisciplinary project in Jarmo (Northern Iraq), for the first time they worked together with a palaeoethnobotanist (Hans Helbaek), a zoologist (Charles Reed), a geologist (Herbert Wright) and a radiocarbon expert (Fred Matson) (Watson 2006. 10-11). Braidwood was also among the first archaeologists to learn about the radiocarbon method. In
1947, he provided his Chicago colleague Williard F. Libby with some of the very first ancient samples to be tested by the new dating method. Soon after, in 1949, while a professor at the University of Chicago (1945-1954), Libby then published his revolutionary results on the radiocarbon dating method (Arnold, Libby 1949; Libby 1952), for which he received the Nobel-prize in 1960.

Again in 1949, Vladimir Milojčić published his influential book on chronological issues of the Neolithic 
in Central and Southeastern Europe, based on comparative stratigraphical observations (Milojčić 1949). Until his untimely death in 1978, Milojčić remained the most convinced advocate of this method, which depended on sound knowledge, a sharp observational spirit, and on the talent of archaeologists for identifying interrelations among distant sites and regions, in the end on subjective, qualitative analysis. At first, probably under the influence of Braidwood, Milojčic was not completely dismissive of the radiocarbon method. Between 1956 and 1958, he collected several charcoal samples from the sites of Argissaand Otzaki-Magoula, not being shy of costs and efforts. In 1959, at the end of his Thessalien-Projekt and the beginning of his professorship in Heidelberg (Hauptmann 1994.531-532), he delivered 12 samples to the Heidelberg laboratory for radiocarbon dating. The results did not support Milojčićs chronological assessments, and from that time on, until late in his life, he became a harsh opponent of the method (Milojčić 1973). However, his critique was not completely unqualified, since, at the very beginning of radiocarbon dating, the need for tree-ring calibration was not understood. As Harald Hauptmann recollects (personal communication, 21.03.2015), it was only shortly before Milojčić's sudden death at the age of 60 that he admitted that ${ }^{14} \mathrm{C}$-dates could be taken into consideration. Following in the footsteps of Braidwood, Milojčić worked with the zoologist Joachim Boessneck and the botanist Maria Hopf (Milojčić 1962).

However not only theoretical and methodological procedures were at issue; Milojčić met Braidwood at least twice in his lifetime: in 1958, at the international congress in Hamburg and the year after, when Braidwood visited Milojčić in Thessaly during his last excavation campaign in Otzaki (Hauptmann 2008. $3)$. This direct contact of the two researchers is important, since it resulted not only in an exchange of ideas, but also in the transfer of the Near Eastern terminology and vocabulary to the Aegean.

For example, when in 1952 Milojčić coined the German word Präkeramikum (Milojčic 1952.315), it is clear that he was not simply translating some few words (e.g., Pre-Pottery-Neolithic, PPN) from English into German, but was actually very carefully transferring the corresponding archaeological notions and concepts from the Near East to the Aegean. The specific formulation $P P N$ was in fact introduced by Kathleen Kenyon during her excavations at Jericho 1952-1958. To be precise, as a result of his excavations at the Tell es Sultan/Jericho layers X-XVII al- ready in 1936, John Garstang had noted that the Early Neolithic was devoid of pottery, but did have a microlithic blade industry (Garstang et al. 1936. 69). Yet, he did not give this period a specific name. Initially, Braidwood (1957.76) rejected the term PPN as meaningless, yet Kenyon justified its usage by the fact that the $P P N$-layers were separated from the PN-layers by a long temporal gap (Kenyon 1957a. 83). In Jericho, 3-4m high levels containing Neolithic pottery overlay meter-high levels devoid of ceramic containers (Kenyon 1957b). At least when speaking of the 'Old World', therefore, the term PPN defines the time before pottery was produced. In comparison, in the Eastern Asiatic Jōmon culture, pottery was in use since at least in the $10^{\text {th }}$ millennium $\mathrm{BC}$, and in the North Pontic steppe since the $8^{\text {th }}$ millennium BC (Piezonka 2014).

As well as the exchange of ideas through the excavation leaders, the team members also brought new and first-hand knowledge from ongoing investigations in Anatolia to Greece. A good example is Hans Helbaek, who was initially part of Braidwood's team, but later also worked in Hacilar with James Mellaart and in Knossos with John D. Evans. Similarly, the archaeozoologist Sebastian Payne, who defined the Aceramic levels in Franchthi Cave, initially worked with David French in Can Hasan (1964-1967), but then with Ian Todd in Asskllı, a site that was identified as Aceramic in 1964 (Payne 1973; 1985). Clearly, since a precise delimitation between the terms Aceramic used in Central and Southwestern Anatolia as opposed to the PPN used in the Levant and Zagros area had not yet been thoroughly discussed, the two terms were often used interchangeably. Understandably, therefore, what we observe is that whether the two different notions were introduced into Greek research strongly depended on the personal relationships between the archaeologists working in the Aegean with their specific colleagues, who could either be active in the Near East (Palestine and Zagros) or in Asia Minor (Central and Western Anatolia).

Yet the usage of the terms Preceramic and Aceramic should not be fortuitous. The Preceramic, in particular, is tied to a specific concept: it covers a period when ceramic products were not yet in use, and this reflects a certain stage in the development of mankind (Nissen 2012.169-170) prior to 7000 calBC. For Knossos in the Aegean, Evans proposed that Aceramic should refer to those levels that do not contain ceramic containers, even though pottery was actually in use in the wider region (Evans 1964; Warren et al. 1968.271). 
In the present paper, we respect this distinction, but argue that a more precise definition of relevant words and concepts will strongly reinforce our understanding of the earliest sedentary communities in the entire Aegean sphere. Certainly, one could object that the concepts involving the production (or not) of ceramic containers cover by no means the complete range of social and cultural behaviour during the MesoNeolithic interface, and indeed that pottery often appears to be more meaningful to prehistoric archaeologists than it may have done to prehistoric communities. Nevertheless, given that these terms are so

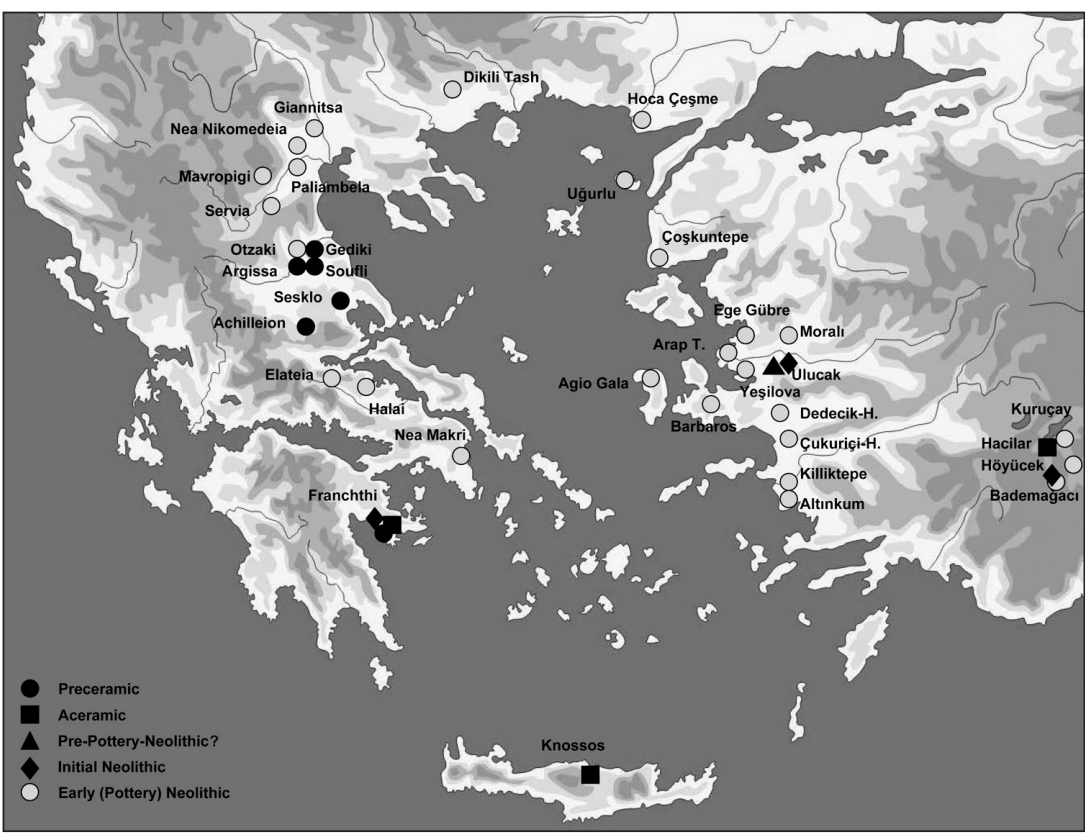

Fig. 1. Sites of the Preceramic, Aceramic, Pre-Pottery-Neolithic, Initial Neolithic and of the Early Pottery Neolithic in the Aegean. widely applied, it does appear useful to study in detail the historical reasons for their initial introduction, and also to account for the alternative meanings given to these terms by different scholars in different regions.

\section{The situation near the Aegean coasts: Thessaly, Crete, the Argolid, and Western Anatolia}

The Preceramic layers of the Argissa-Magoula were excavated in 1956 and 1958 by Milojčić, at that time a professor at the University of Saarbrücken. Some 120 sherds were collected from these lowest levels, some $30 \mathrm{~cm}$ thick (if we take into consideration the so-called pits $\beta-\zeta$, then the height totals up to $50 \mathrm{~cm}$ thickness in the deepest parts). The sherds were interpreted by the excavator as intrusive since they were comparable to the pottery from the above level, and were consequently excluded from discussion (Milojčić 1962.14). In 1957, at a time when Milojčić was pausing from the excavations in Argissa, Dimitrios Theocharis cleared the collapsed northern profile at Sesklo, where he confirmed Milojčićs appraisal that a Preceramic period existed at the start of the Neolithic in Thessaly (Theocharis 1967). Subsequently, Theocharis carried on this work at Soufli-Magoula and also at Achilleion. At both sites, excavations were also conducted thereafter, but no Preceramic levels were encountered. Sesklo and Gediki are therefore the only so-called Preceramic sites where re-investigations would be necessary to clarify the situation (for detailed appraisals of stratigraphic and contex- tual analysis of finds and ${ }^{14} \mathrm{C}$-dates connected to the Preceramic levels, compare Reingruber 2008).

At the end of that decade, in 1957-1960, two new projects were initiated by the British Institute, one led by Mellaart (who had been working with Kenyon in Jericho in 1952: Kenyon 1960.VI) in Hacilar in the SW-Anatolian Lake District, the other by Evans in Knossos on Crete (Fig. 1). Both excavators interpreted the lowest levels of their sites that were found to be devoid of pottery as Aceramic. When Evans reached the $10-20 \mathrm{~cm}$ thin lowest level at Knossos he preferred this label, because he presumed that pottery was not in use yet, but was already circulating in the larger area (Warren et al. 1968.271). Evans later revised his interpretation of Knossos X as a temporary camp, but kept the label Aceramic (Evans 1971.95-117). As it appears, this specific concept of the Aceramic implies that pottery had already been invented, but was not in use on a specific site for various reasons.

In Franchthi Cave, the archaeozoologist Payne was the first to define the so-called 'gray clay-stratum' as pertaining to an early, even Aceramic, group of people (Payne 1973.59-66). In view of the very small number and the small size of the sherds found in this stratum Thomas Jacobsen termed it as "possibly Aceramic Neolithic" (Jacobsen 1969.352). This term is also used by Karen Vitelli (1993). Catherine Perlès variously speaks both of an Aceramic or of a Preceramic phase (Perlès 2001.46, footnote 18). In 2001, 


\begin{tabular}{|c|c|c|c|c|c|c|c|}
\hline Site & Lab. No. & BP & \pm & calBC $1 \sigma$ & $\begin{array}{l}\text { Sample } \\
\text { material }\end{array}$ & Level & $\begin{array}{l}\text { Provenance, } \\
\text { Reference }\end{array}$ \\
\hline Franchthi & GifA-80049 & 8025 & 45 & $7070-6830$ & Charcoal & Final Mesolithic & FAN 169 (Perlès et al. 2013) \\
\hline Franchthi & GifA-80048 & 7990 & 40 & $7050-6820$ & Charcoal & Final Mesolithic & FAN 166 (Perlès et al. 2013) \\
\hline Franchthi & GifA-80046 & 7935 & 40 & $7030-6690$ & Charcoal & Final Mesolithic & FAN 166 (Perlès et al. 2013) \\
\hline Franchthi & GifA-80043 & 7910 & 40 & $6910-6670$ & Charcoal & $\begin{array}{l}\text { Initial Neolithic, } \\
\text { Grey clay stratum }\end{array}$ & $\begin{array}{l}\text { FAN 151, 33g of sherds } \\
\text { (Perlès et al. 2013) }\end{array}$ \\
\hline Franchthi & GifA-80045 & 7875 & 40 & $6780-6640$ & Charcoal & $\begin{array}{l}\text { Initial Neolithic, } \\
\text { Grey clay stratum }\end{array}$ & $\begin{array}{l}\text { FAN 159, no sherds } \\
\text { (Perlès et al. 2013) }\end{array}$ \\
\hline Franchthi & GifA-11016 & 7805 & 40 & & Seed & $\begin{array}{l}\text { Final Mesol./ } \\
\text { Initial Neolithic }\end{array}$ & $\begin{array}{l}\text { FAN 163, no sherds } \\
\text { (Perlès et al. 2013) }\end{array}$ \\
\hline Franchthi & GifA-11455 & 7740 & 50 & & Seed & $\begin{array}{l}\text { Final Mesol./ } \\
\text { Initial Neolithic }\end{array}$ & $\begin{array}{l}\text { FAN 163, no sherds } \\
\text { (Perlès et al. 2013) }\end{array}$ \\
\hline Franchthi & $\begin{array}{l}\text { R_Combine: } \\
\text { GifA-11016+ } \\
\text { GifA-11455 }\end{array}$ & 7780 & 32 & $6650-6590$ & $\begin{array}{l}\text { From same } \\
\text { sample }\end{array}$ & & \\
\hline Franchthi & GifA-11017 & 7780 & 40 & & Seed & $\begin{array}{l}\text { Initial Neolithic, } \\
\text { base of gray clay str. }\end{array}$ & $\begin{array}{l}\text { FAN } 162[1], \text { no sherds } \\
\text { (Perlès et al. 2013) }\end{array}$ \\
\hline Franchthi & GifA-11456 & 7645 & 50 & & Seed & $\begin{array}{l}\text { Initial Neolithic, } \\
\text { base of gray clay str. }\end{array}$ & $\begin{array}{l}\text { FAN } 162 \text { [2], no sherds } \\
\text { (Perlès et al. 2013) }\end{array}$ \\
\hline Franchthi & $\begin{array}{l}\text { R_Combine: } \\
\text { GifA-11017+ } \\
\text { GifA-11456 }\end{array}$ & 7728 & 32 & $6600-6500$ & $\begin{array}{l}\text { From same } \\
\text { sample }\end{array}$ & X-Test fails at $5 \%$ & $\begin{array}{l}\text { X2-Test: } d f=1 \\
T=4.428(5 \% 3.8)\end{array}$ \\
\hline Franchthi & GifA-80044 & 7555 & 40 & $6460-6400$ & Charcoal & $\begin{array}{l}\text { Initial Neolithic, } \\
\text { Grey clay stratum }\end{array}$ & $\begin{array}{l}\text { FAN 158; } 1 \text { sherd } \\
\text { (Perlès et al. 2013) }\end{array}$ \\
\hline Knossos & OxA-9215 & 7965 & 60 & $7040-6770$ & $\begin{array}{c}\text { Charred seeds } \\
\text { (Quercus } \\
\text { evergreen) }\end{array}$ & Level 39/1 & $\begin{array}{l}\text { Trench II, depth } 7.8 \mathrm{~m} \\
\text { (Reingruber, Thissen 2009) }\end{array}$ \\
\hline Knossos X & $B M-124$ & 8050 & 180 & & $\begin{array}{l}\text { Charcoal } \\
\text { (Quercus) }\end{array}$ & $\begin{array}{l}\text { Stratum X; Area AC, } \\
\text { level } 27\end{array}$ & $\begin{array}{l}\text { Central Court, Pit F, Sample 1, } \\
\text { (Barker, Mackey 1963.104) }\end{array}$ \\
\hline Knossos X & $B M-278$ & 7910 & 140 & & $\begin{array}{l}\text { Charcoal } \\
\text { (Quercus) }\end{array}$ & $\begin{array}{l}\text { Stratum X; Area AC, } \\
\text { level } 27\end{array}$ & $\begin{array}{l}\text { Central Court, Pit F, Sample 1, } \\
\text { (Barker et al. 1969.280) }\end{array}$ \\
\hline Knossos X & $\begin{array}{l}\text { R_Combine: } \\
\text { BM-278+ } \\
\text { BM-124 }\end{array}$ & 7964 & 111 & $7050-6700$ & $\begin{array}{l}\text { From same } \\
\text { sample }\end{array}$ & & \\
\hline Knossos X & BM-436 & 7740 & 140 & $6770-6430$ & Seed & $\begin{array}{l}\text { Stratum X, Area AC, } \\
\text { level } 27\end{array}$ & $\begin{array}{l}\text { Central Court, Pit F, Sample 1, } \\
\text { (Barker et al. 1969.280) }\end{array}$ \\
\hline Ulucak VI & Beta-269727 & 7950 & 50 & $7030-6710$ & Charcoal & L13a & $\begin{array}{l}\text { unit } 43 \text { (hearth) } \\
\text { (Çilingiroğlu et al. 2012) }\end{array}$ \\
\hline Ulucak VI & Beta-250265 & 7910 & 50 & $6990-6650$ & Charcoal & L13a & $\begin{array}{l}\text { red painted lime floor } \\
\text { (Çilingiroğlu et al. 2012) }\end{array}$ \\
\hline
\end{tabular}

Tab. 1. Selected ${ }^{14}$ C-dates from Franchthi, Knossos and Ulucak falling into the flat part of the calibration curve (first half of the $7^{\text {th }}$ millennium BC, compare Fig. 6).

she proposed the term Initial Neolithic (compare Perlès 2001.64)

Recently, the lowest levels in Ulucak near Izmir devoid of pottery have been compared to the Anatolian $P P N B$, especially in respect to the "elaborately painted plaster floors" (Çilingiroğlu, Çakirlar 2013. 26). From a technological point of view these floors are considered to be similar to those found in Aceramic Hacilar and at $P P N B$-sites further east (Cilingiroğlu, Cakurlar 2013.24). Detailed descriptions of this specific technology will be essential in support of such broad supra-regional comparisons.

In an attempt to overcome this terminological medley, it has been suggested that we use the name Initial Neolithic to describe the relevant sites not only in W-Anatolia (Ulucak), but also in the Lake District (Hacilar and Bademağaci), as well as for the potterybearing site of Barcın in NW-Anatolia (Özdoğan 2015. Fig. 6). Indeed, the term Initial Neolithic does seem to simplify these complicated terminological issues, 
all the more since in most cases it is not clear whether pottery actually occurred $i n$ situ or was intrusive from levels above. However, and notwithstanding the merits of this specific term, the problem itself cannot be solved by the application of any such new term, but only by large-scale excavations, precise observations and by detailed descriptions of the levels under study, as is the case at the ongoing excavations at Barcin (Gerritsen et al. 2013), Çukuriçi (Horejs 2012) and Ulucak (Cilingiroğlu et al. 2012). The pertinent question, whether a newly founded Neolithic settlement was either coeval with pottery-bearing Neolithic sites, or instead pre-dated such sites, can be resolved also by its radiocarbon-based absolute age.

\section{old and new radiocarbon dates}

At the Central Anatolian site of Çatal Höyük it is now well-established that pottery came into use shortly after 7000 calBC (Thissen 2007.219). Therefore, if the definition of a Preceramic period, comparable with the Near Eastern PPN and of Anatolian formation, should remain an issue in Aegean prehistory, already from terminological considerations (see above) we may expect this phase to have dates prior to at least 6900 calBC. And indeed, the results of the radiocarbon dating method from the early 1960's seemingly corroborate such a high age: charcoal samples from Knossos had been dated to before and/or around 7000 calBC (Barker, Mackey 1963. 104; Barker et al. 1969.279280). The R combine-value of two dates measured on the same sample (Tab. 1) does in fact fall into the first quarter of the $7^{\text {th }}$ millennium calBC (Fig. 2). But a much more reliable date was obtained on carbonised grain, although with a huge standard deviation. It gives a much younger result, dating into the second quarter of that millennium ( $c$. 6750-6500 calBC), similar to a date said to derive from

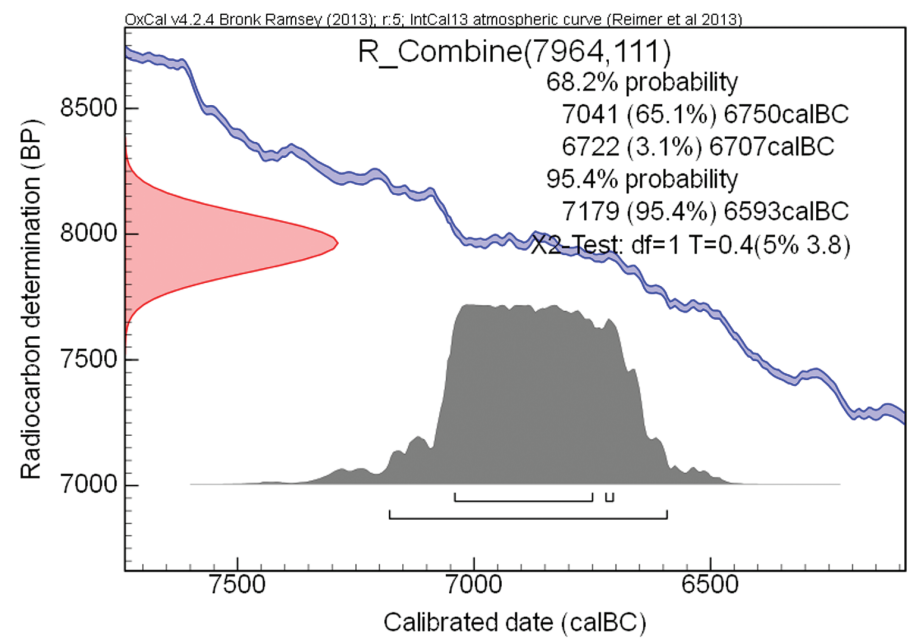

Fig. 2. Radiocarbon dates from Knossos (Reingruber, Thissen 2005.305).

Knossos IX (BM-272: 7570 \pm 150 - compare Reingruber, Thissen 2005.305). These early dates are followed by a gap of around 1000 years. Interestingly, this interpretation - which is not at all self-evident due to the early ${ }^{14} \mathrm{C}$-measurement - were confirmed by the investigations in 1997 ( $E$ fstratiou et al. 2004). A new set of ${ }^{14} \mathrm{C}$-samples from Knossos is now being prepared for dating (personal communication Peter Tomkins, 30 May 2015), and we are looking forward to the results, which are crucial for the inter-

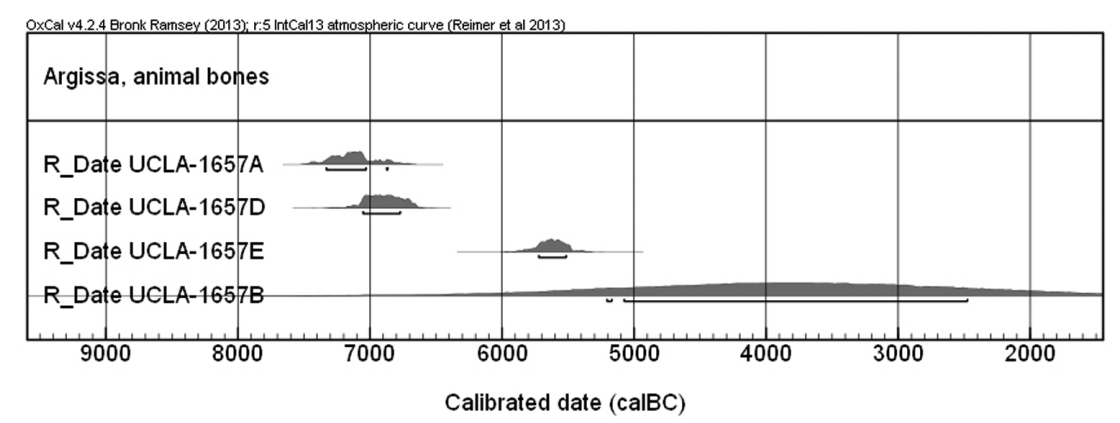

Fig. 3. Radiocarbon dates from Argissa-Magoula on animal bones (Reingruber 2008.157, Tab. 3.4).

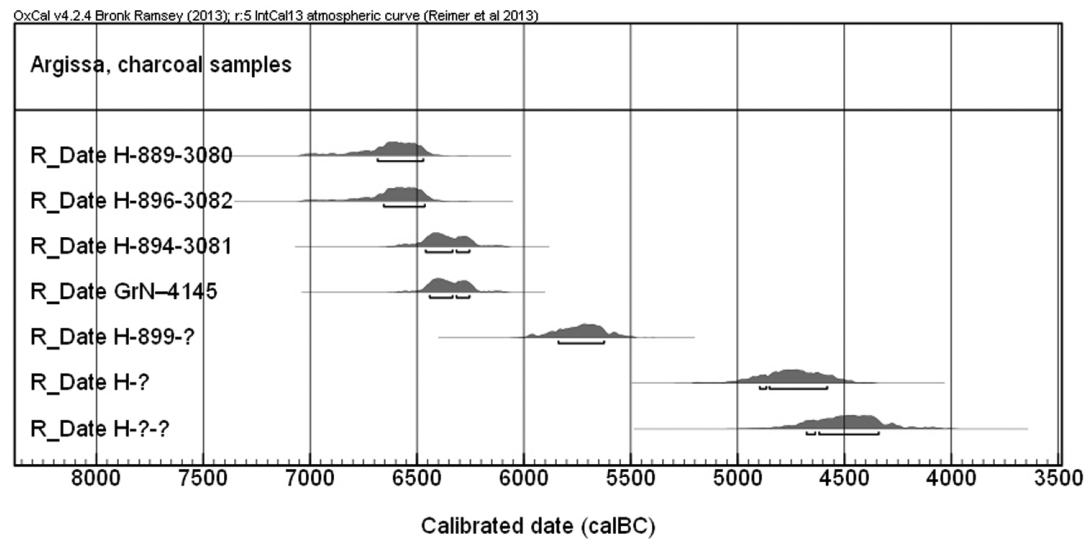

Fig. 4. Radiocarbon dates from Argissa-Magoula on charcoal (Reingruber 2008.157, Tab. 3.4). 
pretation of the site. Meanwhile, let us have a closer look at the presently available ${ }^{14} \mathrm{C}$ data from other sites.

Two radiocarbon dates from Nea Nikomedeia with huge standard deviations date to the end of the $8^{\text {th }}$ millennium (Reingruber, Thissen 2005. 306). Also run in the 1960's, two younger dates from the site with much smaller standard deviations (P-1202 and P-1203A: Vogel, Waterbolk 1967.129) fit well with the sequence presented by Yiouni (1996) that can be dated to around 6150 calBC (compare Reingruber 2008.395-396; Reingruber, Thissen 2009). Therefore, thanks to the AMSmethod, it has been established that the settlement of Nea Nikomedeia was founded some 1000 years later, i.e. not to 7200 calBC (as it previously appeared), but to after 6200 calBC.

At least five bone samples from Argissa-Magoula were dated at the University of Los Angeles and subsequently published by Reiner Protsch and Rainer

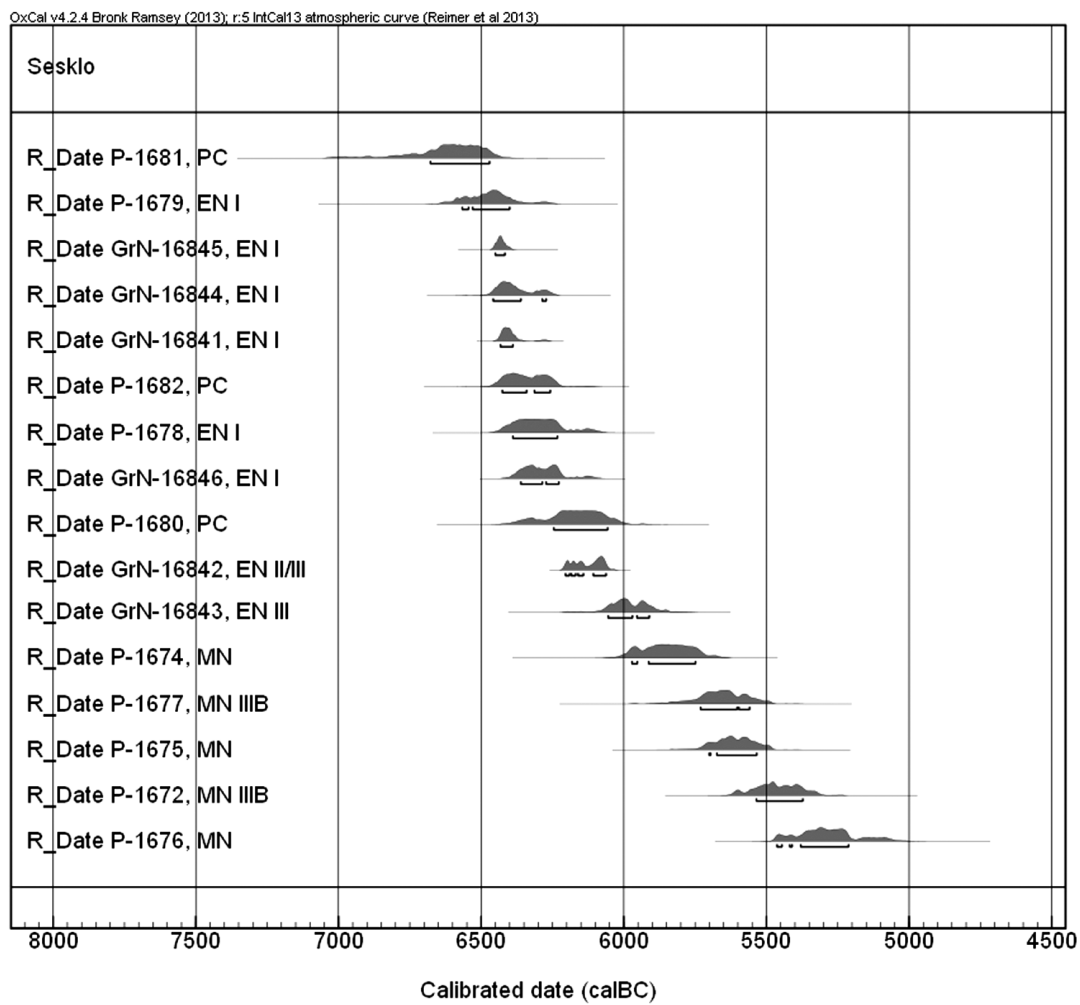

Fig. 5. Radiocarbon dates from Sesklo on charcoal (dates from Lawn 1973).

guably one of the most highly contaminated samples." (http://www.radiocarbon.com/ams-dating-bo nes.htm. (http://www.canadianarchaeology.ca/radio carbon/card/bones.htm; accessed 11.3.2015). On the other hand, the charcoal samples were run at the Heidelberg laboratory and also in Groningen (Vogel, Berger (1973.236) (Fig. 3). Two of these samples have dates between 7300 and 6700 calBC (UCLA-1657A, D), one dates to around 5600 calBC (UCLA-1657E), whilst sample UCLA-1657B failed. These dates must be considered as highly doubtful, in particular due to the later 'career' of the prime author of the article, Reiner Protsch: as director of the Frankfurt radiocarbon laboratory he is known to have faked results on human bones, and it is also reported that he was expelled from the University in 2005 (http:// www.spiegel.de/wissenschaft/mensch/ verurteilter-schaedelforscher-der-professoran-dem-nichts-stimmt-a-631481.html, accessed 11.3.2015). It is open to question whether similar doubts also apply to the UCLAdates from Argissa. However, ${ }^{14} \mathrm{C}$-dating of bone-collagen requires complicated chemical processing, and has become reliable only with the advent of the ${ }^{14} \mathrm{C}$-AMS-technology. Even today, the ultra-filtration method is still in the developmental stage: "Bones are ar-

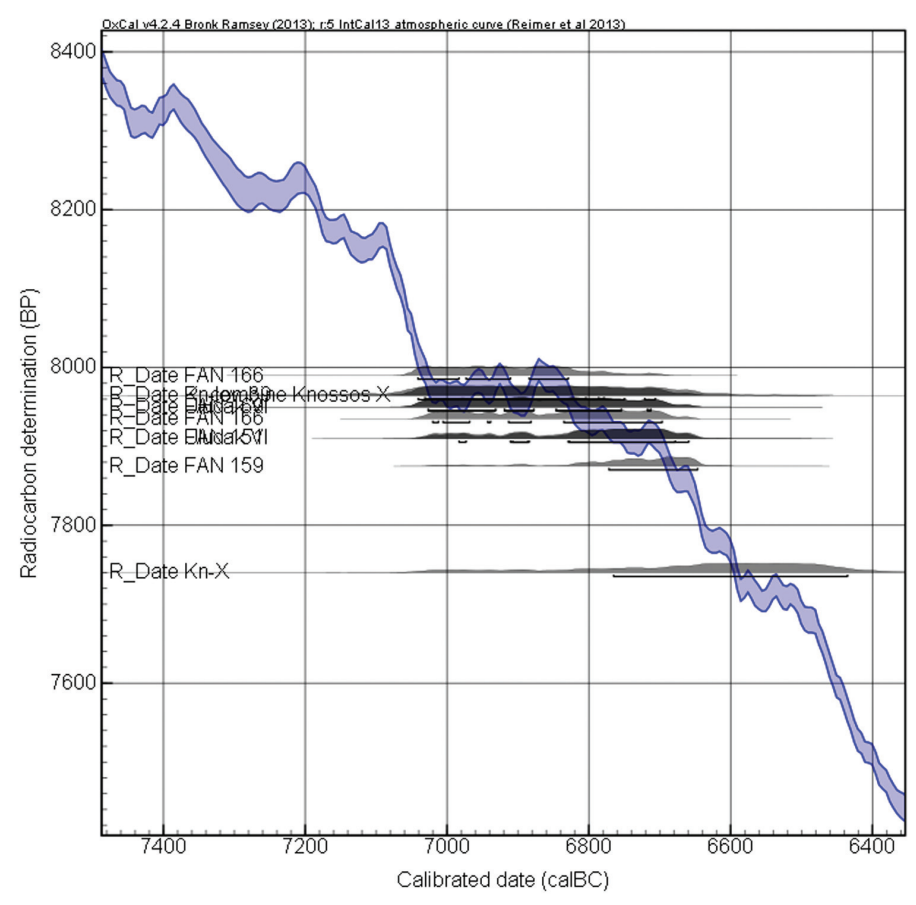

Fig. 6. Calibration curve with radiocarbon dates from Knossos, Bademağacı, Ulucak (compare Tab. 1). 
Waterbolk 1967.129; Hauptmann 1971.365), with results that are consistent with a beginning of the site at around 6500 calBC (Fig. 4). The reliability of these dates was confirmed in 1973 (Lawn 1973. 370 ) by the charcoal-dates from Sesklo that also indicate a starting date around 6500 calBC (Fig. 5).

Serious doubts as to the supposed early age $(\sim 7000$ calBC) of the Preceramic period are therefore advisable, not only due to the generally much younger calibrated ${ }^{14} \mathrm{C}$ ages, but also because of the high amount of sherds found in the alleged Preceramic levels.

A further point that we must address when discussing very early dates around 7000 calBC pertains to the flat shape of the calibration curve between 7000 and 6600 calBC (Tab. 1 and Fig. 6). All dates, even with a narrow spread of BP-values between 7900 and 8000 BP (i.e. $\left.100{ }^{14} \mathrm{C}-\mathrm{yrs}\right)$, will inevitably have read-

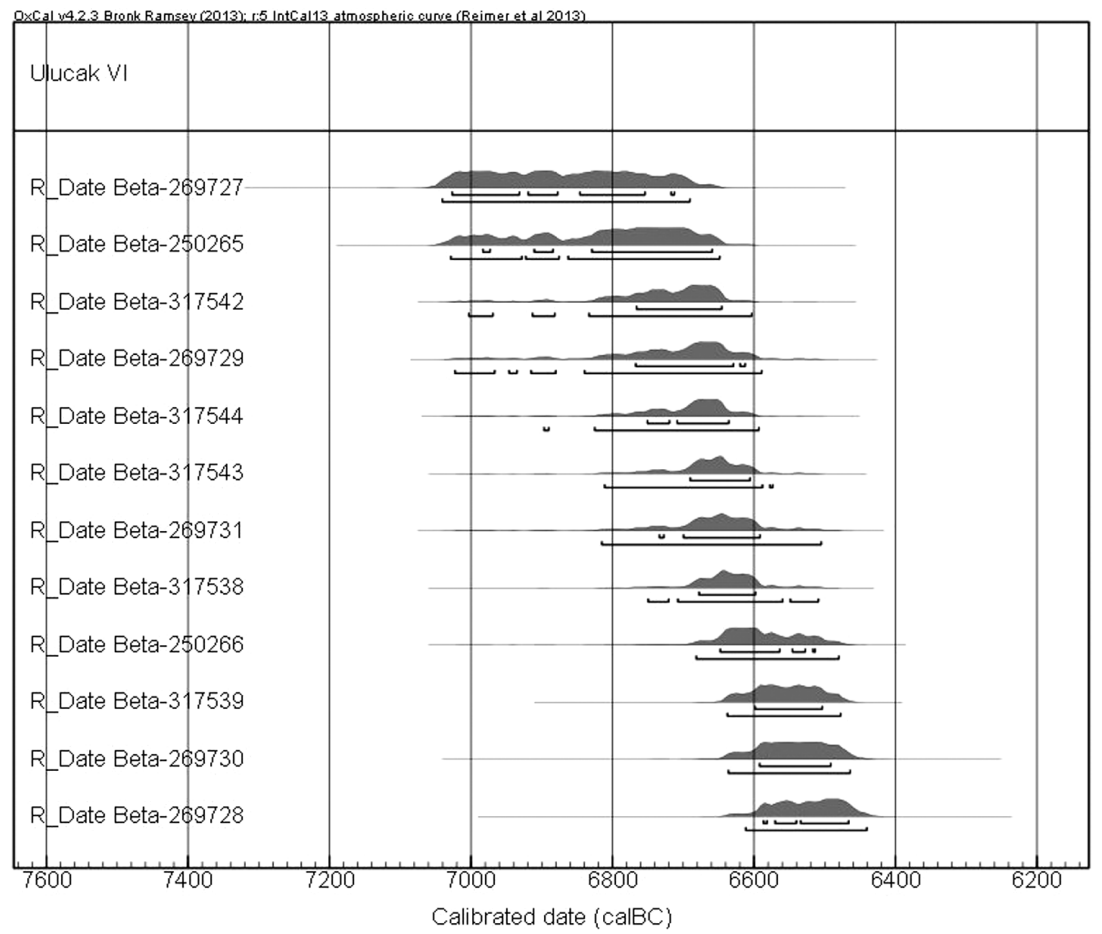

Fig. 8. Radiocarbon dates from Ulucak VI (dates from Çilingiroğlu et al. 2012).

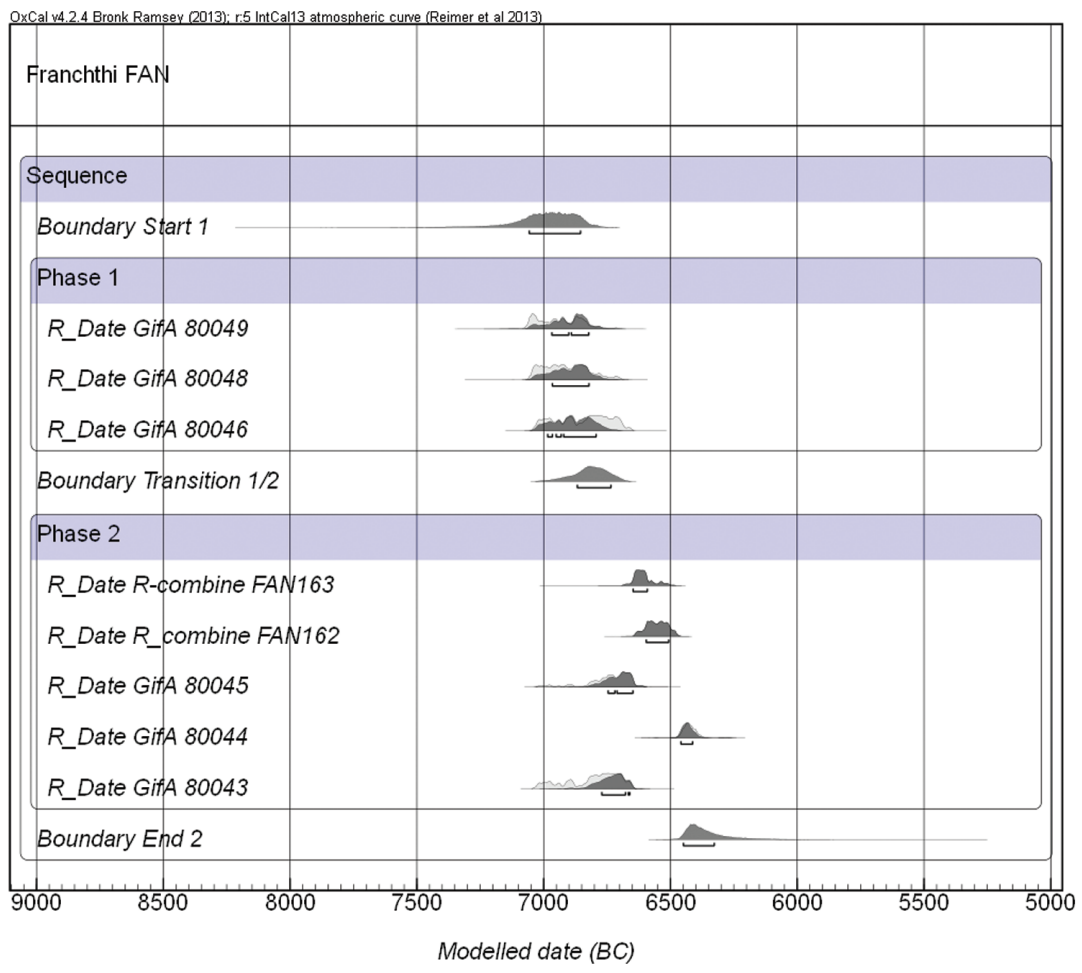

Fig. 7. Radiocarbon dates from Franchthi Cave, trench FAN (dates from Perlès et al. 2013.Tab. 2).

ings within this wide range (i.e. 400 calendric years). Since this and any other specific shape of the calibration curve is due to the secular atmospheric ${ }^{14} \mathrm{C}$ variability, and therefore has a global character, this naturally also applies to the dangers of inadvertently misreading any given ${ }^{14} \mathrm{C}$ dates. This appears to be the case for the recently published (four) dates on two domesticated seed samples from Franchthi Cave that were described as dating to the "early $7^{\text {th }}$ millennium" (Perlès et al. 2013.1001-1015). In actual fact, from Franchthi Cave we do have some dates (excepting short-lived seeds) that are of early $7^{\text {th }}$ millennium age and that indeed fall within the plateau of the calibration curve. However, these dates were measured in charcoal and belong to the Final Mesolithic. Another group of dates is younger and can be placed together with the dates on seeds in the middle of the $7^{\text {th }}$ millennium. They derive from contexts with a very 
small amount of pottery (that might have been intrusive). When modelling the sequence of radiocarbon dates, it is advisable to take into account only samples from a good stratigraphic context, namely those from trench FAN (Fig. 7): the Neolithic dates on short-lived material are demonstrably from the middle of the $7^{\text {th }}$ millennium around 6600-6400 calBC, whereas two dates on long-lived material are, not surprisingly, slightly older.

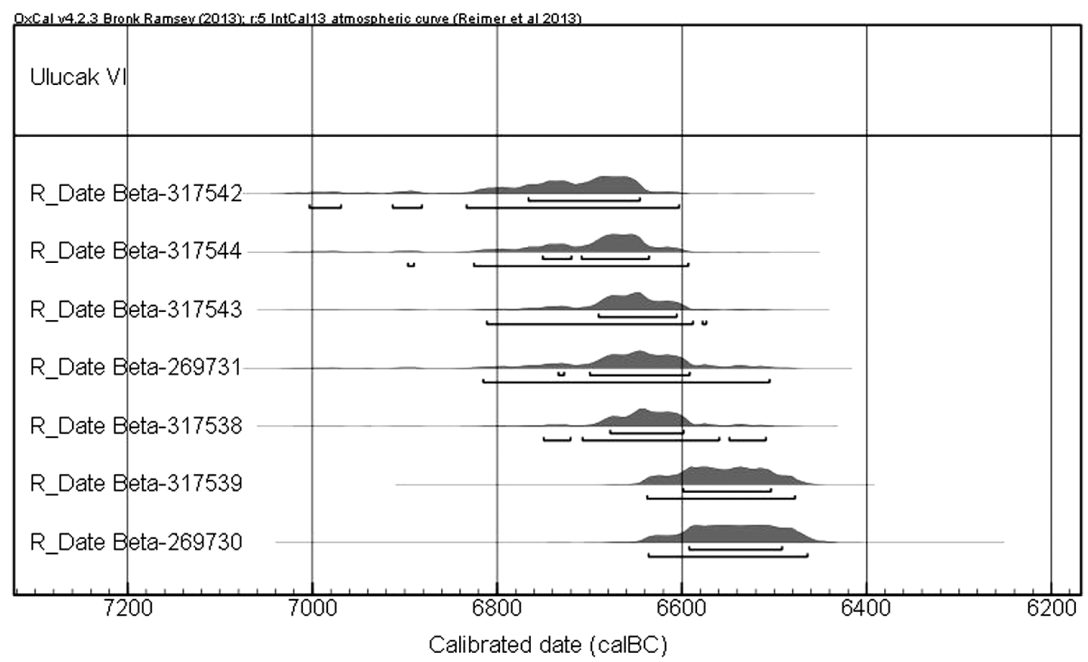

Fig. 9. Results on short-lived samples from Ulucak VI.

Indeed, this result fits perfectly with the interpretation of the dates from Knossos - and the Franchthi dates agree well with the dates from Ulucak near Izmir. There, on the other side of the Aegean, a new body of ${ }^{14} \mathrm{C}$-dates was placed by the excavators in the second quarter of the $7^{\text {th }}$ millennium (Cilingiroğlu et al. 2012.153). Especially when considering the very short-lived (annual) and therefore reliable dates on mainly Emmer wheat, phase VI in Ulucak can indeed be dated between 6700 and 6500 calBC (Figs. 8-9).

In combination, therefore, what we now recognise is that the new dates from Ulucak and Franchthi Cave are not only part of the problem, but also of the solution. When looking at the Aegean as an interrelated communication area, we can now state that the earliest evidence for food-producing communities appeared in its southern part around 6700-6500 calBC and not at 7000 calBC. However, it was obviously only a very short phase, followed by a gap in dates and finds. The next body of dates start some 250 years later in Ulucak, some 500 years later in Franchthi Cave, and at Knossos, probably even 1000 years later (Figs. 10-11).

\section{Discussion and conclusions}

The relative chronology of the Early Neolithic period in Greece was established half a century ago by Milojčić and Theocharis. Only a few years earlier, the first sites of the Pre-Pottery-Neolithic (PPN) were investigated by Kenyon (Jericho) and Braidwood (Jarmo) in the Near East; an Aceramic site was asserted by Mellaart to have existed in Anatolia (Hacllar). Both concepts - that of the Preceramic and that of the Aceramic - were introduced into Greek re- search shortly thereafter (Milojčić 1956; Evans 1964). More recently, other and in respect to the question of pottery-production, more neutral names have been proposed: the Initial Neolithic (Perlès 2001). But again, there is still a strong affiliation with the Pre-Pottery-Neolithic, as requested for the site of Ulucak, and in our view this needs some more thorough specification.

More than fifty years after the important investigations led by the two promoters of Thessalian Neolithic research, Milojčić and Theocharis, a number of rectifications are thus appropriate. It is important to recognise that subsequent excavations in Soufli and Achilleion, as well as the re-evaluation of the documentation in Argissa, did not substantiate the initial interpretation of Milojčić and Theocharis that these sites were founded by Preceramic communities. Not only did the earliest levels in Argissa contain sherds of the Early Ceramic phase, but they were many centuries, if not a millennium, younger than the supposedly coeval sites of the Near-Eastern $P P N$; this is already indicated by careful evaluation of the radiocarbon dates presented in the 1960 's. The initial interpretation of the radiocarbon dates seemingly supported the existence of a Preceramic phase in the Aegean before or around 7000 calBC, since pottery appeared in Central Anatolia only later, between 7000 and 6700 calBC. Even in recent studies, this high temporal frame is often taken as representative of the beginning of the Neolithic in the Aegean. However, a closer look at the shape of the tree-ring calibration curve shows that a plateau occurs between 7000 and 6600 calBC, that is a flat portion with many wiggles. This specific shape of the ${ }^{14} \mathrm{C}$-age calibration curve is the result of the highly variable (and in this case, increasing) pro- 
duction of ${ }^{14} \mathrm{C}$ in the atmosphere. An increasing number of publications in contemporary archaeological literature focus on readings on the upper end of the plateau, but with no further archaeological foundation. However, when modelled with statistical methods, it appears that the lower end at 6600 calBC rather than the upper end at $7000 \mathrm{calBC}$ is the adequate temporal position for many of the samples under study. New dating methods (AMS), new radiocarbon sequences and new statistical approaches (Bayesian modelling) show that the Early Neolithic started in Thessaly around 6500 calBC with an early pottery phase. Nevertheless, a short episode of possibly Aceramic communities can indeed be tra-

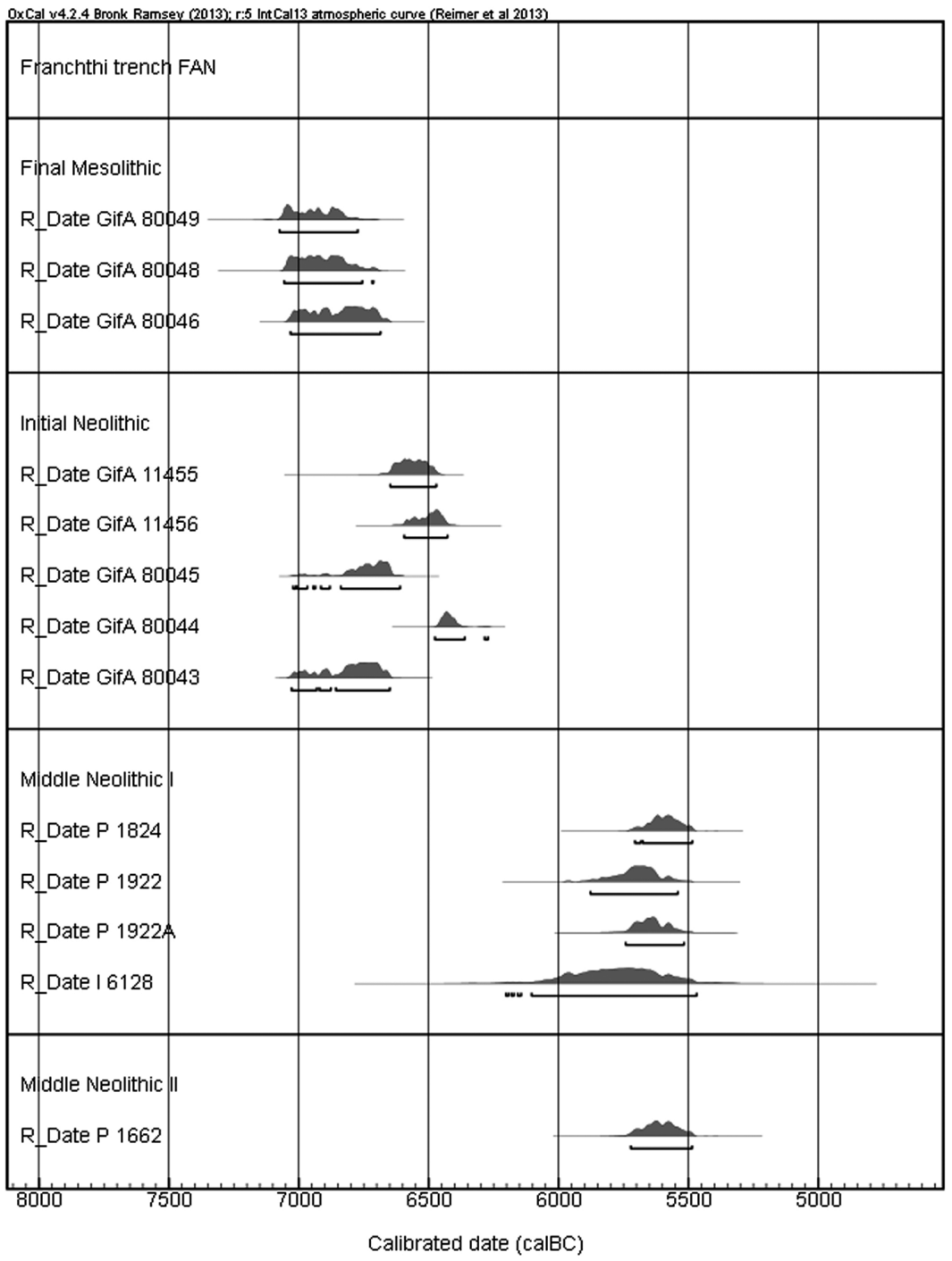

Fig. 10. Radiocarbon dates from Franchthi Cave, trench FAN (dates from Jacobsen, Farrand 1987.Tab. 71). No dates from this trench can be attributed to the EN before 6000 calBC, but date P-2093 from neighbouring FAS-129 with 6940 90 BP (5970-5730 calBC) places the FCP1-pottery phase of the (local) EN in the period after 6000 calBC, coeval with the Thessalian early MN. Ultimately, the dates of the MN I in Franchthi Cave (5700-5500 calBC) are coeval with the MN II-III in Thessaly (Reingruber 2008.Tab. 7.3). ced at three sites in the Southern Aegean (Franchthi Cave, Knossos and Ulucak), dating between 67006500 calBC, after the introduction of pottery in neighbouring Central and Southwestern Anatolia.

With this result, we now face a hitherto unexplored situation: a Preceramic period co-eval with the $P P N$ cannot be verified, nor can the term Aceramic be applied (beyond all doubt) to levels containing sherds that were interpreted as intrusive. At this point, the question must be allowed: why are we (so selectively) looking at the transition from the Mesolithic to the Neolithic in the Aegean always from the Neolithic point of view and why especially from a pottery Neolithic point of view? As already pointed out at by Kotsakis (2003.217221), with this approach we restrict the important transition from one age to the other, in this case from the 'Mesolithic' to the 'Neolithic', to the occurrence (or absence) of ceramic containers. There are manifold solutions to this problem, but perhaps the most prominent is the widely neglected research on a systematic approach to understanding the Mesolithic population and their cultural legacy. For many decades archaeological research has been engaged in the solidification of colonisation and migration models, which ultimately have their roots in the ever-dominant $E x$ Oriente Lux-model. This is despite the fact that, nowadays, in contrast to the research situation some 20 years ago, there is strong evidence for widespread Mesolithic communities especially from the Western Aegean (Reingruber 2008.11-84). We have knowledge of such communities, more recently, from the Southern Aegean (Crete and Gavdos: Kopaka, Matzanas 2009; Strasser et al. 2010) as well as from the Eastern Aegean (Ikaria and Girmeler: Sampson et al. 2012; Takaoğlu et 
al. 2014). It is too early to describe in detail what happened during the transitional decades between 6600 and 6500 calBC, since - for example new data can be expected from Knossos, Ulucak, Çukuriçi Höyük and Barcın; but even when available, it will be of paramount importance to analyse the new data in context with already available evidence from all regions of the Aegean, and this includes finding a common and meaningful terminology.

Although it served as a good tool to explain Neolithisation processes in Thessaly during the 1960's, the so-called Pre-

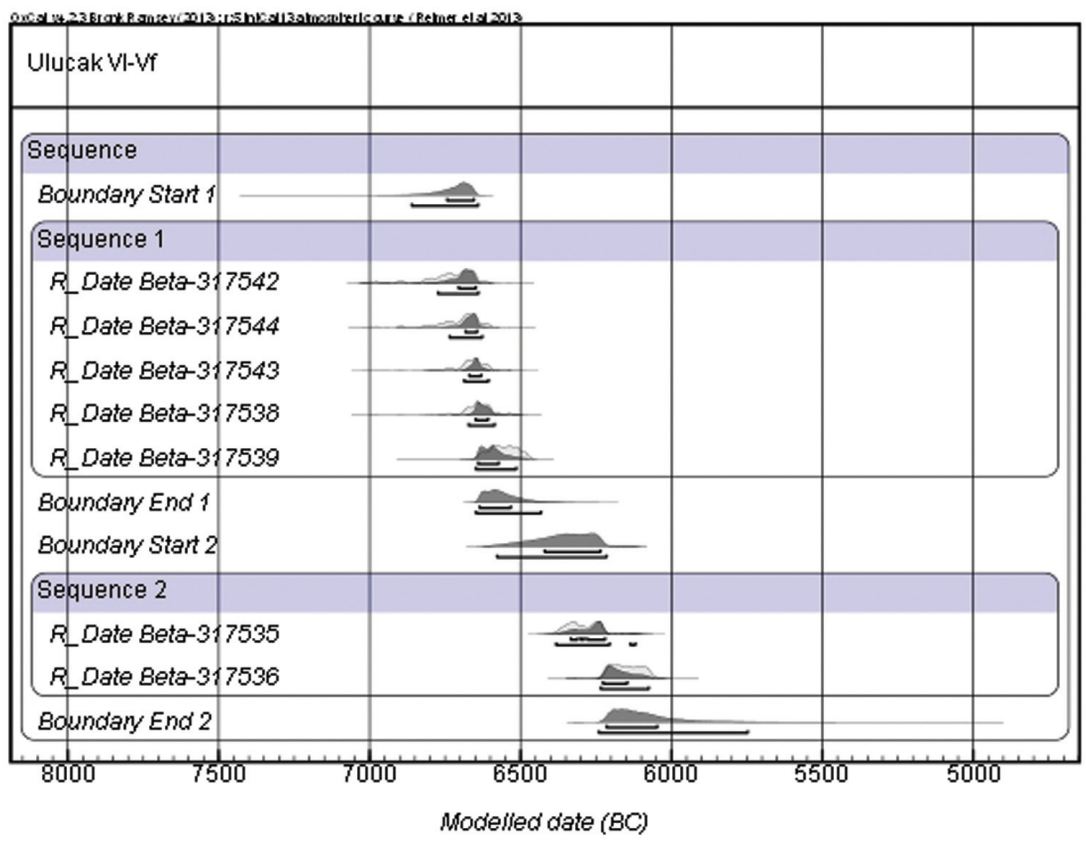

Fig. 11. Modelled radiocarbon dates from Ulucak VI and Vf. ceramic period in Greece is now best understood as a concept that belongs to the history of research. A precise definition of the relevant terms, including the underlying concepts, will certainly remain a matter of future debates. In order to understand and ultimately resolve the long-standing terminological

problems, it will be necessary, in particular, to overcome existing local and national viewpoints. More recent publications (e.g., Lichter 2005) have demonstrated that it is possible to look at the Aegean world in its entirety.

\section{ACKNOWLEDGEMENTS}

My thanks go to Prof. Dr. Mihael Budja for including this paper in the latest volume of 'Neolithic Seminars'. I am indebted to Dr. Bernd Kromer, head of the Heidelberg radiocarbon laboratory, for detailed information concerning the samples submitted by Vladimir Milojčić. Special thanks go to Dr. Laurens Thissen, who provided me with valuable information and new ideas concerning terms and concepts. I also wish to thank the two anonymous reviewers for their improvements on style and comprehensibility. My gratitude includes Prof. Dr. Harald Hauptmann, not only for valuable background information and careful reading of a first draft of this paper, but especially for his constant support.

\section{$\therefore$}

\section{References}

Arnold J. R., Libby W. F. 1949. Age determinations by radiocarbon content: checks with samples of known age. Science 110(2869): 678-680.

Barker H., Mackey J. 1963. British Museum Natural Radiocarbon Measurements IV. Radiocarbon 5: 104-105.

Barker H., Burleigh R. and Meeks N. 1969. British Museum Natural Radiocarbon Measurements VI. Radiocarbon 11(2): 279-280.

Braidwood R. J. 1957. Jericho and its Setting in Near Eastern History. Antiquity 31: 73-81.
Çilingiroğlu A., Çevik Ö. and Çilingiroğlu Ç. 2012. Towards Understanding the Early Farming Communities of CentralWestern Anatolia: Contribution of Ulucak. In M. Özdoğan, N. Başgelen and P. Kuniholm (eds.), Neolithic in Turkey. Vol. 4. New Excavations and New Research. Western Turkey. Arkeoloji ve Sanat Yayınları. Istanbul: 139-175.

Çilingiroğlu C., Çakırlar C. 2013. Towards configuring the neolithisation of Aegean Turkey. Documenta Praehistorica 40: 21-29.

Efstratiou N., Karetsou A., Banou E. S. and Margomenou D. 2004. The Neolithic Settlement of Knossos: New Light 
On an Old Picture. In G. Cadogan, E. Hatzaki and A. Vasilakis (eds.), Knossos: Palace, City, State. Athens: British School at Athens. Athens: 39-49.

Evans J. D. 1964. Excavations in the Neolithic Settlement of Knossos, 1957-60. Part I. British School at Athens 59: $132-240$.

1971. Neolithic Knossos: The Growth of a Settlement. Proceedings of the Prehistoric Society 37(2): 95-117.

Garstang J., Ben-Dor I. and Fitzgerald G. M. 1936. Jericho: City and Necropolis. Annals of Archaeology and Anthropology (Liverpool) 23: 67-100.

Gerritsen F., Özbal R. and Thissen L. 2013. The earliest Neolithic levels at Barcın Höyük, Northwestern Turkey. Anatolica 39: 53-92.

Hauptmann H. 1971. Forschungsbericht über die Ausgrabungen und Neufunde zur ägäischen Frühzeit, 1961-1965. Das Festland und die kleineren Inseln: Steinzeit, besonders Neolithikum. Archäologischer Anzeiger 1971: 348-387.

1994. Milojčić Vladimir. In Neue Deutsche Biographie 17: 531-532. URL: http://www.deutsche-biographie.de/ ppn118582585.html

2008. Vorwort des Herausgebers. In A. Reingruber (ed.), Die deutschen Ausgrabungen auf der ArgissaMagula in Thessalien II: Das frühe und das beginnende mittlere Neolithikum im Lichte transägäischer Beziehungen. Beiträge zur ur- und frühgeschichtlichen Archäologie des Mittelmeer-Kulturraumes 35. Rudolf Habelt. Bonn: 1-5.

Horejs B. 2012. Çukuriçi Höyük. A Neolithic and Bronze Age Settlement in the Region of Ephesos. In M. Özdoğan, N. Başgelen and P. Kuniholm (eds.), The Neolithic in Turkey. Vol. 4. New Excavations and New Research. Western Turkey. Arkeoloji ve Sanat Yayınları. Istanbul: 117-131.

Jacobsen Th. W. 1969. Excavations at Porto Cheli and Vicinity, Preliminary Report II: The Franchthi Cave, 1967-1968. Hesperia: The Journal of the American School of Classical Studies at Athens 38(3). American School of Classical Studies at Athens. Athens: 343-381.

Jacobsen Th. W., Farrand W. R. 1987. Franchthi Cave and Paralia. Maps, Plans and Sections. In Th. W. Jacobsen (ed.), Excavations at Franchthi Cave, Greece, Fascicle 1. Indiana University Press. Bloomington and Indianapolis.

Kenyon K. M. 1957a. Reply to Professor Braidwood. Antiquity 31(122): 82-84.

1957b. Digging up Jericho. Ernest Benn Ltd. London.
1960. Excavations at Jericho. Volume I. Tombs Excavated in 1952-4. British school of archaeology in Jerusalem. London.

Kopaka K., Matzanas C. 2009. Palaeolithic Industries from the Island of Gavdos, Near Neighbour of Crete in Greece. Antiquity 83(321), Project Gallery. http://antiquity.ac.uk/ antiquityNew/projgall/kopaka321

Kotsakis K. 2003. From the Neolithic side: the Mesolithic/ Neolithic interface in Greece. In N. Galanidou, C. Perlès (eds.), The Greek Mesolithic: Problems and Perspectives. British School at Athens Studies 10. British School at Athens. Athens: 217-221.

Lawn B. 1973. University of Pennsylvania Radiocarbon Dates XV. Radiocarbon 15(2): 367-381.

Libby W. F. 1952. Radiocarbon Dating. University of Chicago Press. Chicago.

Lichter C. (ed.) 2005. How did farming reach Europe? Anatolian-European relations from the second half of the $7^{\text {th }}$ through the first half of the $6^{\text {th }}$ millennium cal $B C$. Proceedings of the International Workshop Istanbul, 20-22 May 2004. BYZAS 2. Ege Yayınları. Istanbul.

Milojčić V. 1949. Chronologie der jüngeren Steinzeit Mittel- und Südosteuropas. Gebr. Mann Verlag. Berlin.

1952. Die frühesten Ackerbauer in Mitteleuropa. Germania 30: 313-318.

1956. Die erste präkeramische bäuerliche Siedlung der Jungsteinzeit in Europa. Germania 34: 208-210.

1962. Die deutschen Ausgrabungen auf der ArgissaMagula in Thessalien I. Beiträge zur ur- und frühgeschichtlichen Archäologie des Mittelmeer-Kulturraumes 2. Bonn.

1973. Die C14-Methode im Lichte der komparativ-stratigraphischen Befunde. In UISPP. Actes $d u$ VIIIe congres international des sciences préhistoriques et protohistoriques. Belgrade 1971. Comité National d'Organisation. Belgrade: 3-11.

Nissen H. J. 2012. Geschichte Alt-Vorderasiens. Oldenbourg Grundriss der Geschichte 25. Oldenbourg Wissenschaftsverlag. München.

Özdoğan E. 2015. Current Research and New Evidence for the Neolithization Process in Western Turkey. European Journal of Archaeology 18(1): 33-59.

Payne S. 1973. Animal Bones. In T. W. Jacobsen (ed.), $E x$ cavation in the Franchthi Cave, 1969-1971, Part I. Hes- 
peria: The Journal of the American School of Classical Studies at Athens 42(1). American School of Classical Studies at Athens. Athens: 59-66.

1985. Animal Bones from Așıklı Hüyük. Anatolian Studies 35: 109-122. doi: 10.2307/3642877

Perlès C. 2001. The Early Neolithic in Greece. The First Farming Communities in Europe. Cambridge University Press. Cambridge.

Perlès C., Quiles A. and Valladas H. 2013. Early seventhmillennium AMS dates from domestic seeds in the Initial Neolithic at Franchthi Cave (Argolid, Greece). Antiquity 87: 1001-1015.

Piezonka H. 2014. Jäger, Fischer, Töpfer. Wildbeutergruppen mit früher Keramik in Nordosteuropa im 6. und 5. Jahrtausend v. Chr. Archäologie in Eurasien 30. Dr. Rudolf Habelt GmbH. Bonn.

Protsch R., Berger R. 1973. Earliest Radiocarbon Dates for Domesticated Animals. Europe is added to the Near East as another early center of domestication. Science 179(4070) 235-239. DOI: 10.1126/science.179.4070.235

Reingruber A. 2008. Die deutschen Ausgrabungen auf der Argissa-Magula in Thessalien II: Das frühe und das beginnende mittlere Neolithikum im Lichte transägäischer Beziehungen. Beiträge zur ur- und frühgeschichtlichen Archäologie des Mittelmeer-Kulturraumes 35. Dr. Rudolf Habelt GmbH. Bonn.

Reingruber, A., Thissen, L. $2005 .{ }^{14} \mathrm{C}$ database for the Aegean Catchment (Eastern Greece, Southern Balkans and Western Turkey) 10.000 - 5500 cal BC. In C. Lichter (ed.), How did farming reach Europe? Anatolian-European relations from the second half of the $7^{\text {th }}$ through the first half of the $6^{\text {th }}$ millennium cal $B C$. Proceedings of the International Workshop Istanbul, 20-22 May 2004. BYZAS 2. Ege Yayınları. Istanbul: 295-327.

2009. Depending on ${ }^{14} \mathrm{C}$-Data: Chronological Frameworks in the Neolithic and Chalcolithic of Southeastern Europe. Radiocarbon 51: 751-770.

Sampson A., Kaczanowska M. and Kozłowski J. K. 2012. Mesolithic occupations and environments on the island of Ikaria, Aegean, Greece. Krakow: Polish Academy of Arts and Sciences. Folia Quaternaria 80: 5-40.

Strasser T. F., Panagopoulou E., Runnels C. N., Murray P. M., Thompson N., Karkanas P., McCoy F. W. and Wegmann K. W. 2010. Stone Age Seafaring in the Mediterranean: Evidence from the Plakias Region for Lower Palaeolithic and Mesolithic Habitation of Crete. Hesperia 79(2): 145190.

Takaoğlu T., Korkut T., Erdoğu B. and Işın G. 2014. Archaeological evidence for $9^{\text {th }}$ and $8^{\text {th }}$ millennia BC at Girmeler Cave near Tlos in SW Turkey. Documenta Praehistorica 41: 111-118.

Theocharis D. R. 1967. I Avgi tis Thessalikis Proistorias. Arkhi kai Proimi Exelixi tis Neolithikis. Volos: Filarkhaios Etairia Volou. (in Greek)

Thissen L. 2007. Die Anfänge der Keramikproduktion in der Türkei - ein Überblick. In C. Lichter (ed.), Vor 12.000 Jahren in Anatolien: Die ältesten Monumente der Menschheit. Badisches Landesmuseum. Konrad Theiss Verlag. Stuttgart: 218-229.

Vitelli K. D. 1993. Franchthi Neolithic Pottery Vol 1: Classfication and Ceramic Phases 1 and 2. In T. W. Jacobsen (ed.), Excavations at Franchthi Cave, Greece, Fascicle 8. Bloomington and Indianapolis.

Vogel J., Waterbolk H. 1967. Groningen Radiocarbon Dates VII. Radiocarbon 9: 129.

Warren P., Jarman M. R., Jarman H. N., Shackleton N. J. and Evans J. D. 1968. Knossos Neolithic, Part II. British School at Athens 63: 239-276.

Watson P. J. 2006. Robert John Braidwood, 1907-2003. A Biographical Memoir. Washington. URL: http://www. nasonline.org/publications/biographical-memoirs/memoir-pdfs/braidwood-robert.pdf

Yiouni P. 1996. The Early Neolithic Pottery: Technology, Typology, Functional Analyses. In K. A. Wardle (ed.), Nea Nikomedeia I: The Excavation of an Early Neolithic Village in Northern Greece 1961-1964. The British School of Archaeology at Athens, Suppl. 25. London: 55-196. 